\title{
Respon Guru Pendidikan Anak Usia Dini terhadap MOOCs berbantuan Augmented Reality
}

\author{
Eko Risdianto ${ }^{\bowtie}$, Murni Yanto르, Muhammad Kristiawan³, Guntur Gunawan ${ }^{4}$ \\ Pendidikan Fisika, Universitas Bengkulu ${ }^{(1)}$ \\ Manajemen Pendidikan, Institut Agama Islam Negeri Curup( ${ }^{(2)}$ \\ Ilmu Pendidikan, Universitas Bengkulu( ${ }^{(3)}$ \\ Ilmu Perpustakaan dan Informasi slam, Institut Agama Islam Negeri Curup ${ }^{(4)}$ \\ DOI: $10.31004 /$ obsesi.v5i2.907
}

\begin{abstract}
Abstrak
Tujuan penelitian ini untuk menganalisis respon terhadap kebutuhan model blended learning berbasis MOOCs berbantuan augmented reality bagi guru PAUD. Teknik sampling yang digunakan adalah pusposive sampling dengan sampel data pada penelitian ini yaitu 90 guru. Penelitian ini adalah merupakan bagian dari penelitian $\mathrm{R} \mathrm{n} D$ yaitu pada tahap analisis kebutuhan, Instrumen yang digunakan dalam penelitian ini yaitu lembar angket kebutuhan terhadap model blended learning berbasis MOOCs berbantuan augmented reality bagi guru PAUD. Hasil penelitian ini menunjukkan bahwa instrumen yang digunakan valid dan reliable dan berdasarkan analisis dengan model rasch dengan aplikasi winstep mendapatkan hasil bahwa kualitas respon angket ini sangat baik. Hasil penelitian menyebutkan guru PAUD sangat setuju bahwa dibutuhkannya model blended learning berbasis MOOCs berbantuan augmented reality. Penelitian ini memberi kontribusi bagi praktisi pendidikan agar berinovasi membuat MOOCs berbantuan augmented reality sebagai model blended learning untuk guru PAUD.
\end{abstract}

Kata Kunci: blended learning; moocs; augmented reality; guru paud

\begin{abstract}
The purpose of this paper analyzed the response to the need for a blended learning model based on MOOCs assisted by augmented reality for Early Childhood Education teachers. The sampling technique used was purposive sampling with the data sample in this study were 90 teachers. This research is part of the $\mathrm{R} n \mathrm{D}$. The instrument used in this study is the needs questionnaire sheet for the blended learning model based on MOOCs assisted augmented reality for Early Childhood Education teachers. The results of this study indicate that the instruments used were valid and reliable and based on the analysis with the Rasch model with the Winstep application, the results showed that the quality of the response to this questionnaire is very good. The results obtained that Early Childhood Education teachers strongly agree that they need a blended learning model based on MOOCs assisted augmented reality. This paper contributes to education practitioners to innovate in making MOOCs assisted augmented reality as blended learning models for PAUD teachers.
\end{abstract}

Keywords: blended learning; moocs; augmented reality; early childhood education teachers

Copyright (c) 2020 Eko Risdianto, Murni Yanto, Muhammad Kristiawan, Guntur Gunawan

$\square$ Corresponding author :

Email Address : eko_risdianto@unib.ac.id (Bengkulu, Indonesia)

Received 9 November 2020, Accepted 26 November 2020, Published 29 November 2020 


\section{PENDAHULUAN}

Revolusi industri 4.0 sering disebut sebagai Era Disrupsi, Era Inovasi atau juga disebut sebagai Ancaman bagi incumbent. Pada era ini kita bisa melihat bahwa teknologi informasi dan komunikasi dimanfaatkan sepenuhnya di hampir lini kehidupan manusia (Risdianto, 2019b). Perkembangan teknologi digital di era Industri 4.0 saat ini telah membawa perubahan dan mempengaruhi berbagai aspek kehidupan manusia, termasuk di bidang pendidikan (Putrawangsa \& Hasanah, 2018). Dunia pendidikan merupakan dunia yang menjadi prioritas dalam kehidupan manusia (Peranti, Purwanto, \& Risdianto, 2019). Pendidikan merupakan suatu hal yang sangat penting bagi kehidupan seseorang untuk dapat menumbuhkan dan mengembangkan kemampuan atau potensi yang dimiliki oleh orang tersebut. Pendidikan dapat membuat seseorang merubah dari hal yang tidak tahu menjadi tahu, pendidikan juga membuat seseorang untuk dapat mencapai cita-cita yang diinginkan, meningkatkan mutu dan kecerdasan seseorang serta dapat mengembangkan potensi yang ada dalam diri seseorang sehingga dapat berguna dalam kehidupan bermasyarakat (Liani, Hamdani, \& Risdianto, 2018).

Pengembangan kemampuan dan kompetensi harus dilakukan oleh setiap guru dalam semua jenjang pendidikan termasuk guru pendidikan anak usia dini (PAUD). Berdasarkan data dari Dirjen GTK mengatakan bahwa nilai rerata UKG pendidik TK pada tahun 2015 hingga 2017 terus mengalami peningkatan, artinya perbaikan nilai merupakan salah satu cara pengembangan diri pendidik dalam meningkatkan kompetensi sehingga menjadi guru profesional (Maiza \& Nurhafizah, 2019). Pada anak usia dini ini, anak mengalami perkembangan dalam tahap mengeksplor dan berinteraksi langsung dengan lingkungan sekitarnya. Anak usia dini biasanya cenderung senang dengan hal-hal yang baru yang didapatnya melalui aktivitas bermain (Pebriana, 2017). Artinya pembelajaran untuk anak usia dini tidak hanya dilaksanakan dengan interaksi di dalam ruang belajar tetapi juga di dalam ruang bermain. Namun, pembelajaran anak usia dini seyogyanya dapat dilakukan sebagai pembelajaran jarak jauh. Pembelajaran Jarak Jauh (PJJ) memerlukan teknologi informasi dan komunikasi (jaringan internet), teknologi yang dapat memberikan solusi dan kemudahan (Zamzami, 2020).

Pada era teknologi informasi saat ini dan dengan pesatnya perkembangan teknologi, manfaat komputer telah dirasakan diberbagai sektor kehidupan (Sriwahyuni, Risdianto, \& Johan, 2019). Dalam sektor pendidikan, pemanfaatan komputer sudah berkembang tidak hanya sebagai alat yang dipergunakan untuk urusan keadministrasian, melainkan juga dimungkinkan untuk digunakan sebagai sarana pembelajaran (Putri, Risdianto, \& Rohadi, 2019).

Dengan berkembangnya zaman, banyak hal-hal baru yang muncul dalam dunia pendidikan, salah satunya yaitu penerapan model blended learning. Blended learning merupakan gabungan pembelajaran online dan face-to-face (Wardani, Toenlioe, \& Wedi, 2018). Blended learning dapat meningkatkan pengalaman mengajar guru dan belajar siswa karena memungkin mereka untuk terlibat aktif pada pembelajaran di kelas dan pembelajaran jarak jauh dengan menggunakan teknologi seperti e-learning (Oktarina, Budiningsih, \& Risdianto, 2018). Blended learning memiliki kelebihan antara lain: 1) Flexibility, artinya mahasiswa dapat berkontribusi dalam diskusi pada waktu dan tempat yang mereka pilih secara individual, 2) Participation, artinya bahwa semua mahasiswa dapat berpartisipasi di dalam proses belajar karena mereka dapat mengatur waktu dan tempat untuk ikut serta, 3) Pembelajaran memiliki waktu yang lebih banyak sehingga dapat lebih berhati-hati dalam berargumentasi serta lebih dalam merefleksikan pandangan dan pendapatnya (Prayitno \& Masduki, 2017). Penelitian terdahulu mengenai blended learning sudah dilakukan oleh Khoiroh dkk (2017). Penelitian ini menyatakan bahwa hasil belajar siswa dan motivasi siswa dalam mengikuti pembelajaran menggunakan model pembelajaran blended learning lebih tinggi dibandingkan dengan hasil belajar siswa menggunakan model pembelajaran langsung. Penelitian lainnya juga dilakukan oleh Fandianta dkk (2013). Pada penelitian ini, hasil pre-pos tes menunjukkan perbedaan yang 
bermakna terhadap peningkatan pengetahuan mahasiswa yang mengikuti pembelajaran menggunakan e-learning dibandingkan dengan pembelajaran konvensional $(p<0,05)$. Terdapat persepsi positif terhadap aspek diskusi, tugas, kuis/ujian, dan ketersediaan bahan ajar pada penggunaan e-learning. Dari penelitian terdahulu mengenai blended learning maka kita dapat melakukan penelitian lanjutan dengan melakukan pengembangan, dalam hal ini kita menggunakan model tambahan yaitu yang dikenal dengan MOOCs (Massive Open Online Courses).

MOOCs hadir sebagai sebuah model baru pendidikan dan pembelajaran, yang menggunakan internet dalam menyampaikan materi perkuliahan di perguruan tinggi dan lembaga pendidikan bergengsi dunia, menciptakan semacam revolusi dan orang-orang ini saling bergabung untuk melakukan kursus berkelanjutan. MOOCs merupakan hit terbaru dalam pembelajaran online, dan diposisikan sebagai alternatif untuk program pendidikan tinggi tradisional. Sejalan dengan fenomena ini, MOOCs juga telah membawa revolusi ke sektor pendidikan dalam waktu singkat, membuka peluang bagi pedagogi baru dan model bisnis yang memungkinkan ribuan siswa mengakses secara bebas. Akses gratis ini memungkinkan orang di seluruh dunia untuk mendaftar di MOOCs (Emigawaty, 2017). Penelitian terdahulu mengenai MOOCs telah dilakukan oleh Ismail (2018). Hasil kajiannya mendapati bahwa penggunaan MOOCs dapat meningkatkan daya literasi terhadap MOOCs, motivasi dan minat pelajar, seterusnya menjadikan proses pembelajaran lebih menarik disamping dapat menambah alat bahan bantu mengajar (ABBM) yang ada. Dari penelitian yang terdahulu maka kita dapat melakukan penelitian lanjutan untuk menganalisis kebutuhan guru terhadap pembelajaran dengan model MOOCs ini.

Selain model pembelajaran, dalam dunia pendidikan juga terjadi perkembangan pada aspek teknologi yang disebut dengan teknologi dalam bidang pendidikan seperti augmented reality. Augmented Reality adalah bentuk teknologi interaktif yang menggabungkan teknologi virtual dengan dunia nyata. Augmented Reality adalah kombinasi dari proyek 3D ke lingkungan nyata. Dengan teknologi AR, kita dapat mewujudkan gambar 2D menjadi 3D sehingga terlihat realistis. Beberapa alasan untuk menggunakan teknologi AR adalah bahwa menggunakan AR dalam pembelajaran dapat membantu menjelaskan konsep abstrak atau tidak dapat dengan jelas hadir dalam pembelajaran, teknologi AR dapat diakses melalui perangkat gadget kapan saja (Risdianto, 2019). Kelebihan dari augmented reality yaitu: lebih interaktif, efektif dalam penggunaan, dapat diimplementasikan secara luas dalam berbagai media, modeling objek yang sederhana karena hanya menampilkan beberapa objek, pembuatan yang tidak memakan terlalu banyak biaya, dan mudah untuk dioperasikan. Kekurangan dari augmented reality yaitu: sensitif dengan perubahan sudut pandang, pembuatan belum terlalu banyak, dan membutuhkan banyak memori pada peralatan yang dipasang (Setiawan \& Nugraha, 2017). Penelitian terdahulu mengenai teknologi augmented reality telah dilakukan oleh Mustaqim dan Kurniawan (2017). Hasil dari penelitian ini menunjukkan bahwa melaui Augmented Reality, guru dapat membuat media pembelajaran yang menyenangkan, interaktif, dan mudah digunakan. Augmented Reality juga dapat menggantikan modul pembelajaran yang belum ada di sekolah dalam bentuk virtual atau maya. Dari hasil penelitian ini kita bisa melakukan pengembangan dengan menganalisis respon guru terhadap kebutuhan pembelajaran dengan menggunakan augmented reality.

Dalam melakukan analisis terhadap data yang diperlukan dalam penelitian biasanya digunakan model rasch. Pengukuran inteligensi dengan Rasch model menghasilkan analisis statistik kesesuaian (fit statistics) yang memberikan informasi pada peneliti apakah data yang didapatkan memang secara ideal menggambarkan bahwa orang yang mempunyai abilitas tinggi memberikan pola jawaban terhadap aitem sesuai dengan tingkat kesulitannya (Suryani, 2018). Ini menunjukkan bahwa pemodelan Rasch juga dapat digunakan untuk analisis tanggapan kuesioner yang diberikan kepada responden tentang kebutuhan terhadap model blended learning berbasis MOOCs dan augmented reality. 
Dari uraian di atas maka perlu dilakukan penelitian dengan tujuan untuk melakukan analisis respon guru PAUD terhadap kebutuhan model blended learning berbasis MOOCs dan augmented reality.

\section{METODOLOGI}

Penelitian ini merupakan bagian dari penelitian $\mathrm{RnD}$ (Research and Development) dengan model ADDIE yaitu pada tahap analisis kebutuhan. Penelitian di lakukan di provinsi Bengkulu tahun 2020 dengan Populasi yang diambil dalam penelitian ini yaitu guru PAUD. Teknik sampling yang digunakan adalah purposive sampling dengan sampel yang diambil adalah 90 guru PAUD. Teknik pengumpulan data dalam penelitian ini yaitu menggunakan angket untuk mengetahui tingkat kebutuhan guru atau tenaga pendidik terhadap model blended learning berbasis MOOCs dan augmented realty. Instrumen penelitian yang digunakan dalam penelitian analisis kebutuhan ini adalah lembar angket kebutuhan guru terhadap model blended learning berbasis MOOCs dan augmented realty bagi guru atau tenaga pendidik. Teknik analisis data dalam penelitian ini adalah teknik analisis kuantitatif dan disimpulkan secara kualitatif. Teknik analisis kuantitatif dalam hal ini adalah pengukuran kebutuhan guru atau tenaga pendidik secara statistik yang mengacu pada jawaban angket penelitian yang diisi oleh 90 guru atau tenaga pendidik. Untuk mengetahui dan menguji kualitas angket yang diberikan, dilakukan dengan sebuah analisis pemodelan menggunakan model rasch. Persentase diperoleh berdasarkan perhitungan skala likert yang dimodifikasi sedangkan untuk analisis dengan model rasch dilakukan dengan menggunakan aplikasi winstep. Dengan skala likert, maka variabel yang akan diukur dijabarkan menjadi indikator variabel. Selanjutnya indikator tersebut dijadikan pedoman dalam menyusun item-item yang berupa pertanyaan ataupun pernyataan (Sugiyono, 2010).

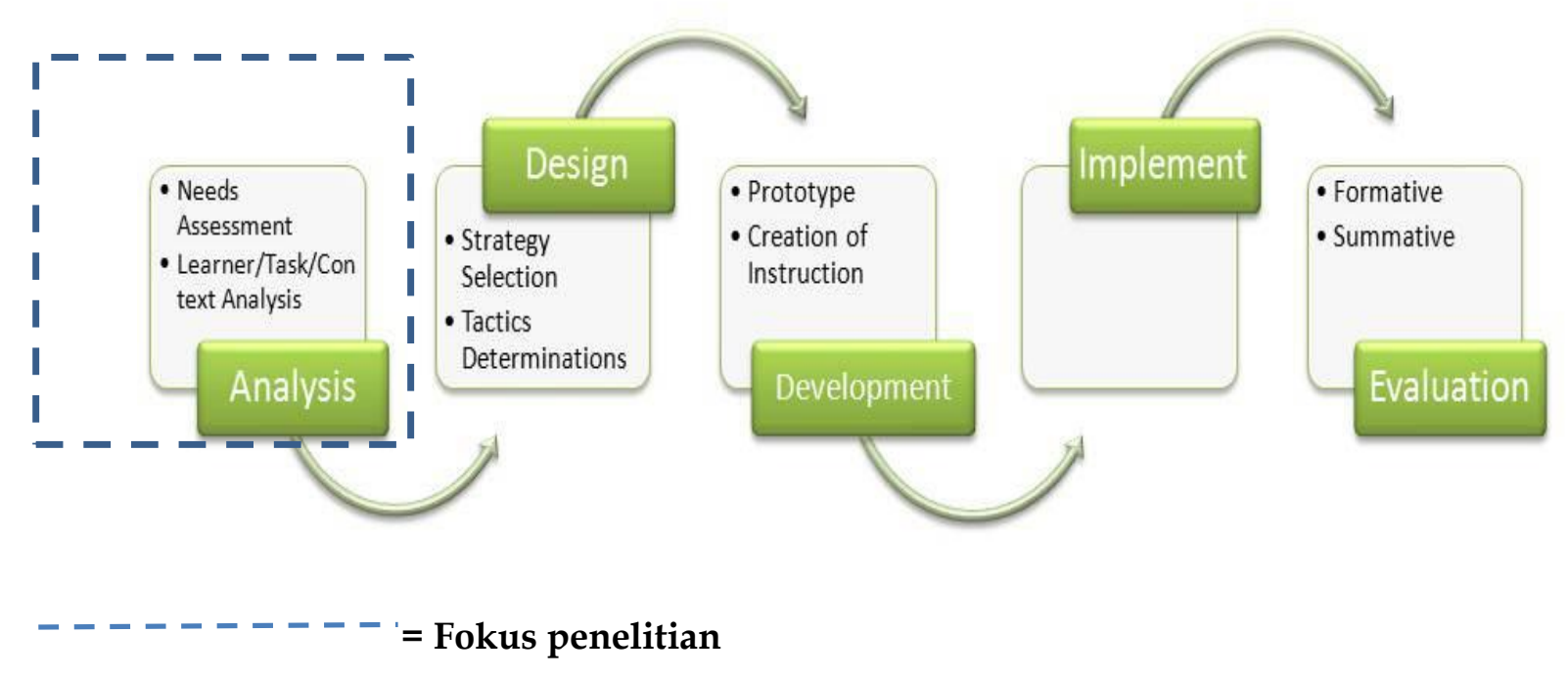

Gambar 1. Desain penelitian

\section{HASIL DAN PEMBAHASAN}

Angket yang digunakan dalam penelitian ini adalah angket kebutuhan guru atau tenaga pendidik dengan 4 pilihan jawaban. Penilaian menggunakan skala likert dengan skor maksimum item butir angket tersebut adalah 4 dan minimum adalah 1 . Butir-butir pertanyaan yang digunakan dalam angket diuji validitas dan reliabilitasnya untuk mengetahui apakah instrument tersebut layak digunakan untuk memperoleh data yang dibutuhkan oleh peneliti. Untuk hasil perhitungan validitas data dapat dilihat pada tabel 1. 
Tabel 1. Case Processing Summary

\begin{tabular}{ll|l|l}
\hline & & $\mathbf{N}$ & \% \\
\hline \multirow{3}{*}{ Cases } & Valid & 15 & 100,0 \\
\cline { 2 - 4 } & Excluded $^{a}$ & 0 & 0 \\
\cline { 2 - 4 } & Total & 15 & 100,0 \\
\hline
\end{tabular}

Tabel 2 Reliability Statistics

\begin{tabular}{c|c}
\hline $\begin{array}{c}\text { Cronbach's } \\
\text { Alpha }\end{array}$ & $\begin{array}{c}\mathbf{N} \text { of } \\
\text { Items }\end{array}$ \\
\hline 0,878 & 90 \\
\hline
\end{tabular}

Pada tabel 2 Cross Processing Summary memberikan informasi bahwa terdapat 15 pertanyaan $(\mathrm{N})$ valid. Tidak terdapat data yang dikeluarkan (Exclude). Total 15 data $(\mathrm{N})$ diolah atau $100 \%$ data diolah. Berdasarkan perhitungan hasil perhitungan reliabilitas data dapat dilihat pada tabel 2. Pada tabel 3 Reliability Statistics menunjukkan hasil perhitungan reliabilitas data dengan menggunakan metode alpha Cronbach dengan skor 0,863. Kemudian nilai ini $(0,863)$ dibandingkan dengan tabel nilai $r$ product moment. Dengan menggunakan distribusi tabel $r$ tersebut untuk $\alpha=0,05$, maka didapat nilai $=0,207$, kemudian dibandingkan dengan nilai Cronbach's Alpha sebesar 0,863. Kaidah keputusannya adalah :

Reliabel : jika $r_{\text {hitung }}$ lebih besar dari nilai $r_{\text {tabel }}\left(r_{\text {hitung }}>r_{\text {tabel }}\right)$

Tidak reliabel : jika $\mathrm{r}_{\text {hitung }}$ lebih kecil dari nilai $\mathrm{r}_{\text {tabel }}\left(\mathrm{r}_{\text {hitung }}<\mathrm{r}_{\text {tabel }}\right)$

Dengan demikian dapat diputuskan bahwa nilai alpha $0.878>0.207$, sehingga data tersebut dikatakan reliabel atau terpercaya.Untuk mengetahui persentase respon guru atau tenaga pendidik terhadap kebutuhan model blended learning berbasis MOOCs dan augmented reality, dapat diolah melalui data pada table 3.

Tabel 3. Hasil Data Respon Terhadap Kebutuhan Guru PAUD

\begin{tabular}{ccccc}
\hline Responden & $\begin{array}{c}\text { Skor Total } \\
\text { (n) }\end{array}$ & $\begin{array}{c}\text { Skor Maksimal } \\
\text { (N) }\end{array}$ & $\begin{array}{c}\text { Persentase } \\
P=\frac{n}{N} \times 100 \%\end{array}$ & Kategori \\
\hline $\begin{array}{c}90 \text { Guru } \\
\text { atau }\end{array}$ & 4964 & 5400 & $91,92 \%$ & $\begin{array}{c}\text { Sangat } \\
\text { Setuju }\end{array}$ \\
$\begin{array}{c}\text { Tenaga } \\
\text { Pendidik }\end{array}$ & & & & \\
\hline
\end{tabular}

Tabel 3 memberikan informasi bahwa guru PAUD sangat setuju dengan model blended learning berbasis MOOCs dan augmented reality, ini ditunjukkan dengan besar persentase yang diperoleh sebesar 91,92 \% dari persentase maksimum $100 \%$. Dan sesuai dengan table interpretasi skala likert untuk data dengan persentase $76 \%-100 \%$ di kategorikan sangat setuju.

Untuk mengetahui kualitas responden tersebut dalam mengisi data dengan benar maka menggunakan aplikasi winstep dengan model rasch. Langkah yang pertama yaitu mencari variable maps.

Pada peta sebelah kiri terlihat ada tujuh orang guru/responden $(03,07,10,11,14,16$, $25,29,31,33,40,41,46,48,50,57,72$ ) yang memiliki tingkat abilitas tertinggi (sangat setuju), ke tujuh belas guru/responden itu mendapatkan nilai maksimum yang bisa didapatkan. Mendapatkan abilitasnya yang tertinggi yaitu (+6 logit). Ada juga yang nilai logit nya diatas (+5 logit) yaitu guru/responden dengan kode nomor $(19,27,28,36,54,55,56,58,60)$ ke sembilan guru/ responden tersebut juga memiliki abilitas tinggi (sangat setuju) dari angket yang telah didapatkan.

Untuk peta sebelah kanan terdapat 15 pertanyaan yang mempunyai validitas tingkat kesulitan yang beragam mulai dari P10, P8 dan P4 yang paling susah untuk di jawab menuju ke P1 yang paling mudah untuk dijawab. Dari data angket yang diperoleh pertanyaan dengan tingkat kesulitan terendah itu pertanyaan 1 (P1), guru/responden dengan abilitas rendah 
(tidak setuju) responden nomor $(23,45,68,52,64)$. Hal ini menunjukkan hal yang bagus karena dalam hal ini setiap pertanyaan yang diberikan bisa memberikan informasi yang mengenai abilitas responden yang di uji.

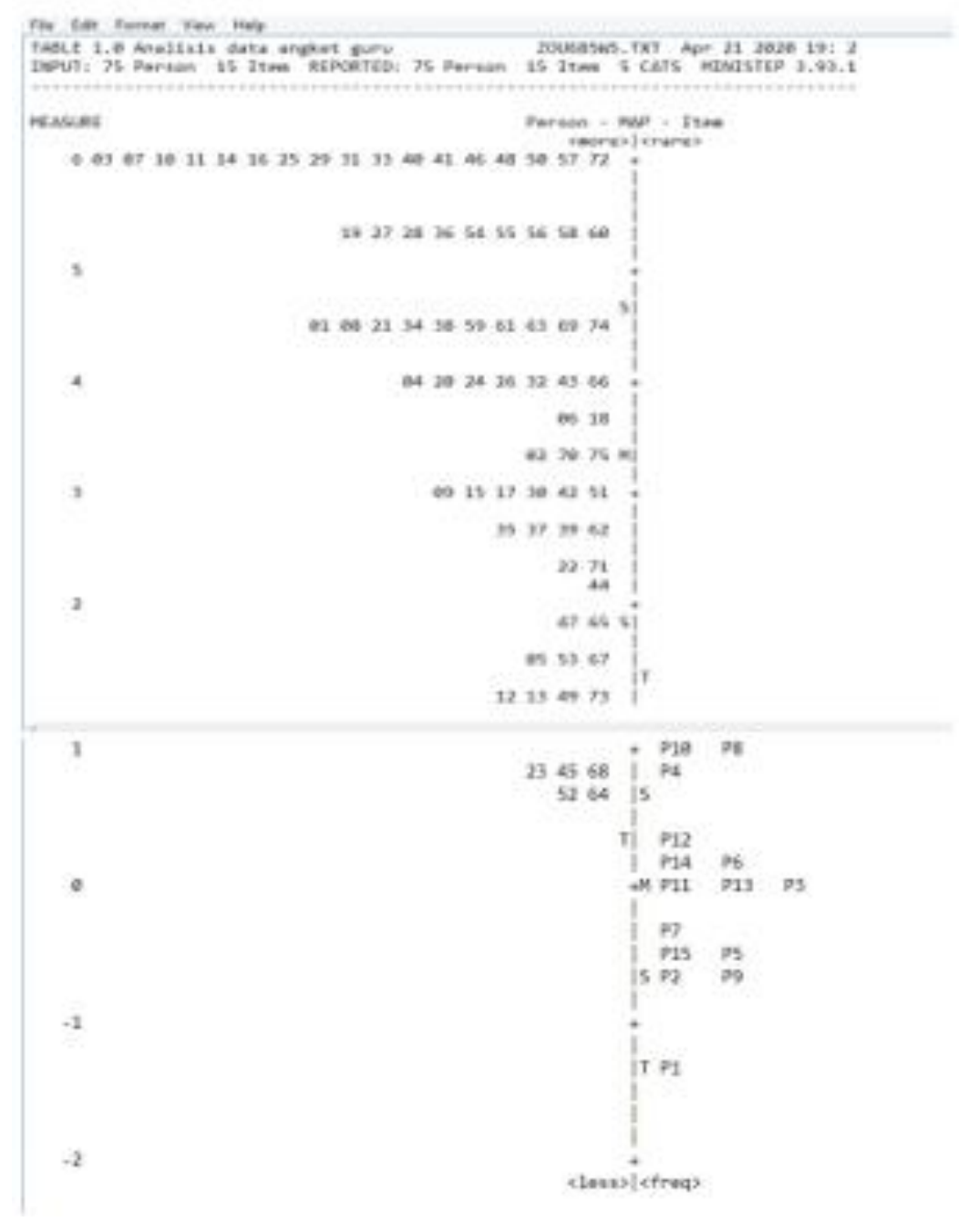

\section{Gambar 2. Variable Maps}

Jika dibandingkan jarak antara M-S-T (rata-rata, 1SD dan 2SD) pada peta wright di atas terlihat bahwa sebaran untuk abilitas responden (sebelah kiri) lebih lebar dibandingkan dengan sebaran tingkat kesulitan pertanyaan (sebelah kanan) .

Jika membandingkan rata-rata logit item dengan logit person, terlihat bawa logit person lebih besar (+1 logit) hal ini menunjukan bahwa abilitas keseluruhan hanya sedikit lebih tinggi dibandingkan dengan kesulitan pertanyaan. Dari peta terlihat bahwa dari 75 guru/responden semuanya sukses menjawab pertanyaan yang di ajukan kepada mereka dengan benar. Hal ini juga menunjukkan dari respon guru PAUD terhadap pertanyaan yang diajukan, guru PAUD sangat setuju (abilitas tinggi). Menganalisis butir pertanyaan menggunakan output table 13. Item measure.

Pada kolom total count terbaca ada angka 75 berarti semua guru/responden menjawab setiap pertanyaan yang telah diberikan. Dari tabel diatas mengurutkan tingkat kesulitan dari yang tertinggi (P8) sampai yang terendah (P1), yang ditunjukkan pada kolom Measure. Informasi tingkat kesulitan pertanyaan dapat memudahkan kita mengidentifikasi mana pertanyaan yang sulit dan mana pertanyaan yang mudah untuk dijawab oleh responden.

Tabel 4. output table 13. Item measure 


\begin{tabular}{|c|c|c|c|c|c|c|c|c|c|c|c|c|}
\hline Persan: & \multicolumn{12}{|c|}{ Iten STATISTICS: VEASURE ORDER } \\
\hline $\begin{array}{l}\text { ENTKY } \\
\text { muvets }\end{array}$ & $\begin{array}{l}\text { roral } \\
\text { Scokt }\end{array}$ & $\begin{array}{l}\text { Total } \\
\text { cowit }\end{array}$ & intasine & $\begin{array}{l}\text { mooet। } \\
5, \mathrm{E} .1\end{array}$ & inse & Fit I ast & into & $\begin{array}{l}\text { IPInEAs } \\
\text { icoun. }\end{array}$ & $\begin{array}{l}\text { in }-a, \mid \\
\exp , 1\end{array}$ & $\mid \begin{array}{l}\text { Exact } \\
\text { cess }\end{array}$ & $\begin{array}{l}\text { MATCHI } \\
\text { EXPSI }\end{array}$ & Iten \\
\hline ह & 265 & 75 & 1.05 & .231 & I.84 & $-., 3] 1.14$ & .61 & 1.62 & .631 & 65,5 & 70,41 & Pg \\
\hline 10 & 265 & 75 & 1.65 & $.23 \mid$ & 1.63 & $-1.1\}$,95 & . 이 & I. .67 & $.63 \mid$ & 78.7 & $70.4 i$ & P10 \\
\hline 4 & 269 & 75 & .80 & .26 & 1.35 & $.9 \mid 1.45$ & 1.5 & .57 & $.63 \mid$ & 74.1 & 73.81 & P4 \\
\hline 12 & 275 & 75 & .33 & .38 & 1.67 & -1.81 .57 & -1.6 & .74 & .621 & 82.8 & 75.41 & P12 \\
\hline 6 & 276 & 75 & .24 & .31 & 1.02 & $.2\} .94$ & -.1 & .60 & .621 & 67.2 & 75.81 & P6 \\
\hline 14 & 277 & 75 & .14 & .31 & I. .74 & $-.91 \quad .73$ & -.9 & | . .68 & $.61 \mid$ & 1 82.8 & 76.21 & P14 \\
\hline 3 & 278 & 75 & .05 & $.32 \mid$ & I. .94 & $-.1 \mid 1.69$ & .4 & 1.60 & .611 & 81.8 & 76.91 & P3 \\
\hline 11 & 278 & 75 & .05 & .32 & .85 & $-.5 \mid .68$ & -1.1 & | .68 & .61 & 82.8 & 76.91 & P11 \\
\hline 13 & 278 & 75 & .05 & .32 & 1. .66 & -1.31 .61 & -1.4 & 1. .71 & $.61 \mid$ & 84.5 & 76.91 & P13 \\
\hline 7 & 281 & 75 & -.27 & .33| & | .92 & $-.31 . .92$ & -.1 | & 1.60 & .58 & 79.3 & $78.6 !$ & P7. \\
\hline 5 & 283 & 75 & $-.4 \%$ & $.34 \mid$ & 1.25 & $1.1 \mid 1.43$ & 1.2 & .45 & $.56 \mid$ & 74.1 & 79.71 & ps. \\
\hline 15 & 283 & 75 & -.49 & $.34 \mid$ & I. 85 & -71.66 & $-1.0 \mid$ & 1.62 & $.56 \mid$ & 81.0 & 29.71 & p15 \\
\hline 2 & $2 B 4$ & 75 & -.61 & , 351 & .71 & $-1.4\} .56$ & -1.31 & 1.65 & $.55 i$ & 86.2 & $8 a, 2\}$ & $p 2$ \\
\hline 9 & 284 & 75 & -.61 & ,351 & | . 87 & $-.5\}, 94$ & . ब) & I .98 & $.55 i$ & 66.2 & Bo. 21 & p9 \\
\hline 1 & 269 & 75 & -1.27 & | & $\mid 4,48$ & $9.1 \mid 3.08$ & 2.81 & 1.27 & .481 & 93,1 & 63.11 & P1 \\
\hline NeAM & 277.7 & 75.0 & .60 & 31 & 1,12 & $.2 \mid 1,05$ &,- 1 & & & 79.4 & 76.91 & \\
\hline P.SD & 6.7 & .0 & .63 & $.84 \mid$ & I . .92 & $2.5 \mid-61$ & $1,2 \mid$ & & & 7,4 & 3.41 & \\
\hline
\end{tabular}

Untuk mengetahui tingkat kesesuaian pertanyaan (item fit), yang maknanya sesuai dengan model ideal pengukuran. Pilih table 10. Item fit order. Pada tabel 5 terlihat bahwa indikator item fit untuk semua butir pertanyaan yaitu outfit means square $(0,5<$ MNSQ $>1,5)$, outfit Z-standars $(-2,0<\mathrm{ZSTD}<+2,0)$, dan point measure correlation $(0,4<\mathrm{Pt}$ Measure corr $<0,85$ ), tidak menunjukan adanya sembarang masalah. Dengan kata lain semua pertanyaan yang diberikan bisa dipahami dengan baik oleh semua responden, tidak ada pertanyaan yang miskonsepsi. Hal ini sesuai dengan penyataan yang disampaikan oleh (Sumintono, Bambang \& Widhiarso, 2015) yang menyatakan bahwa untuk melihat kualitas butir penyataan apakah layak/sesuai maka dilihat dari 3 kriteria di atas. Jika suatu pernyataan sudah memenuhi satu kriteria saja maka item penyataan yang diberikan dapat atau layak digunakan.

\section{Tabel 5. table 10. Item fit order}

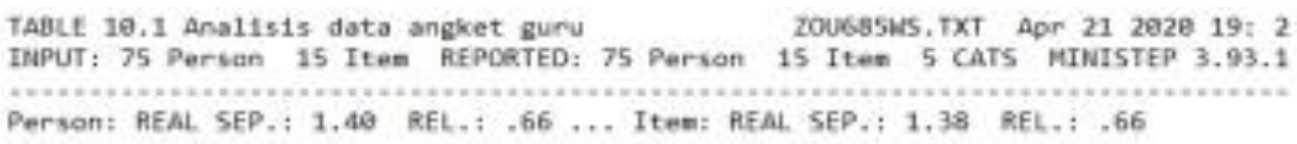

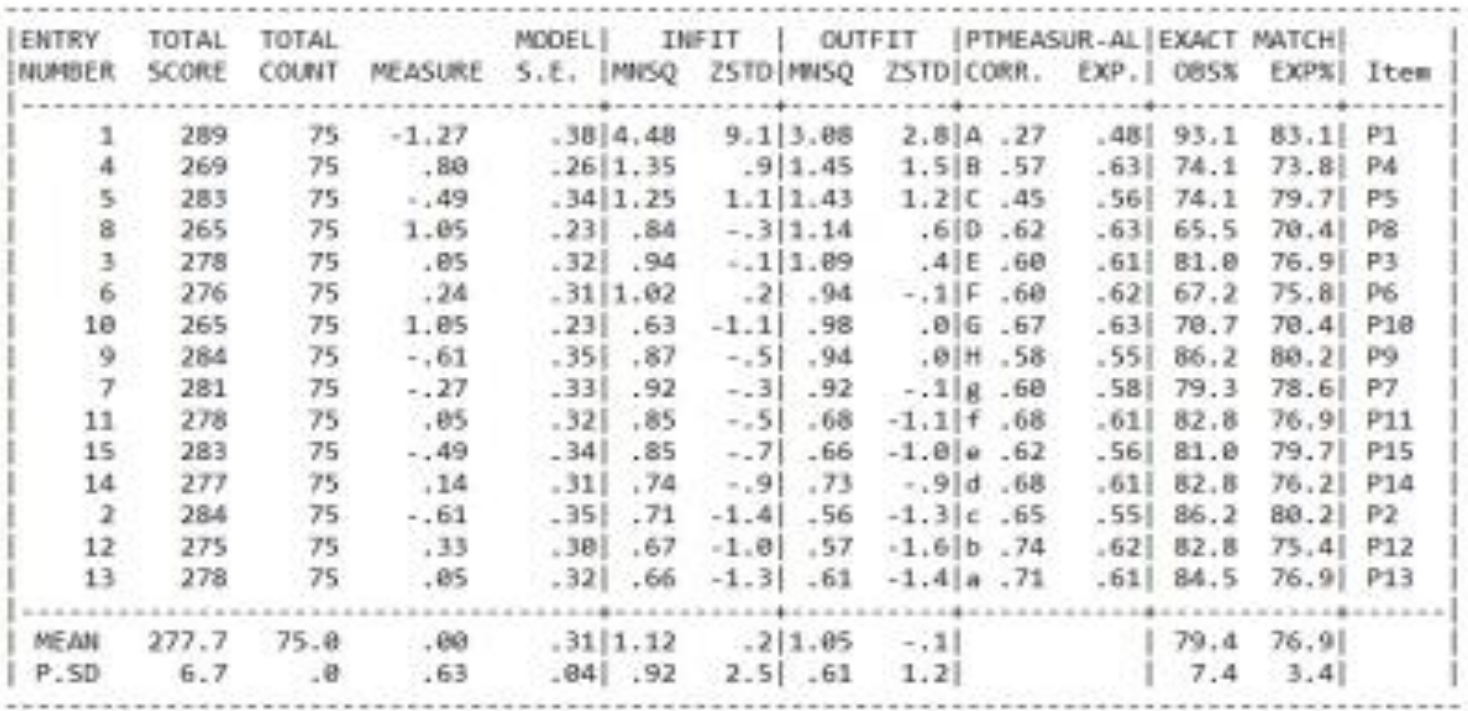


Terlihat pada tabel 5 bahwa butir pertanyaan P3, P5, P6 dan P10, yang mengandung satu kriteria yang tidak fit yaitu nilai infit mean-square yang lebih besar daripada nilai 1,5, Hal ini juga bisa ditunjukkan dengan grafik ICC seperti pada gambar 2. yang ada tanda panah pada P3 itu adalah pola respon yang tidak sesuai (misfit). Yang ada tanda panah pada P5 pada gambar 4 adalah pola respon yang tidak sesuai (misfit). Yang ada tanda panah pada P6 pada gambar 5 adalah pola respon yang tidak sesuai (misfit). Yang ada tanda panah pada P10 pada gambar 6 adalah pola respon yang tidak sesuai (misfit).

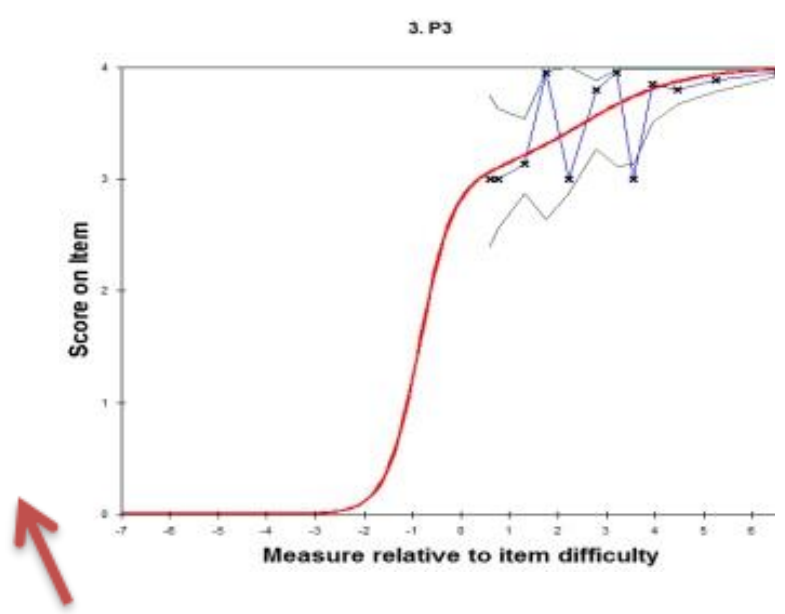

Gambar 3. nilai infit mean-square

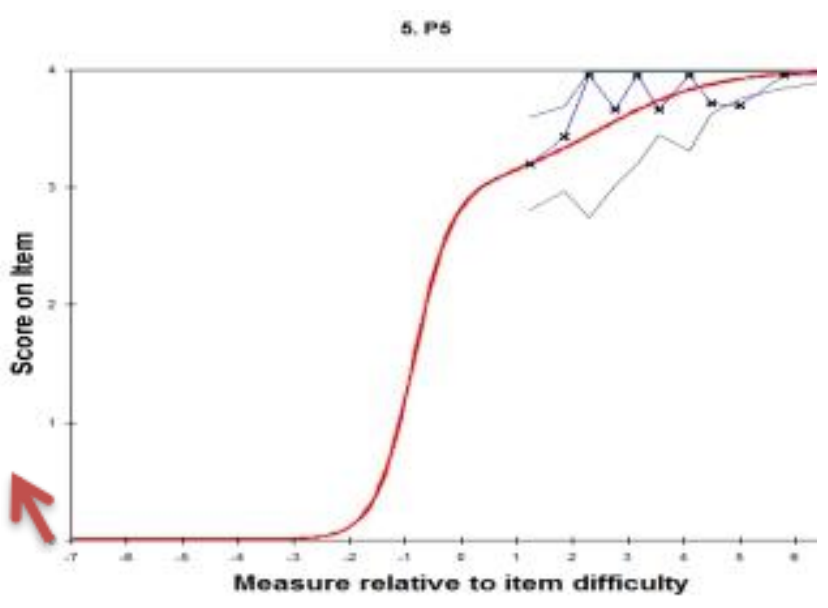

Gambar 3. nilai infit mean-square

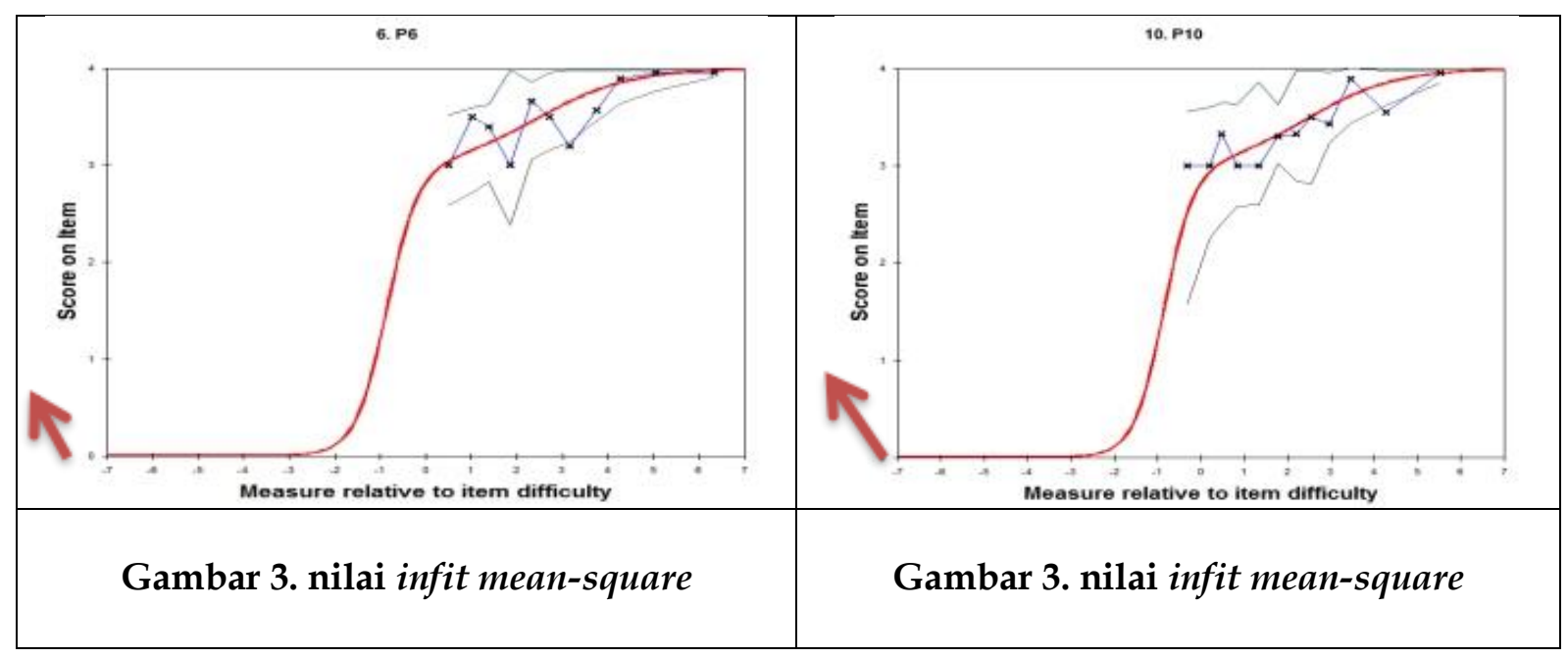

Untuk menganalisis abilitas guru, maka kita pilih table 17 Person Measure. Akan ditampilkan secara berurutan data abilitas guru dari tertinggi sampai yang terendah, seperti pada tabel 6. Dengan 15 butir pertanyaan dan setiap butir skor maksimal adalah 4, maka jumlah skor maksimal untuk angket secara keseluruhan adalah 60 dan skor minimalnya adalah 4 . Di sisi lain, kolom total count menyatakan berapa banyak butir pertanyaan yang telah dijawab oleh guru tersebut.

Kolom measure menyatakan tingkat abilitas dalam satuan logit. Pada tabel di atas, abilitas yang paling tinggi dimiliki oleh 03 (measure $=+6,57$ logit) hingga abilitas yang paling rendah yang dimiliki oleh 64 (measure $=0,65$ logit). Hal ini menunjukan skor mentah yang sama (total skor) juga abilitas tinggi dapat diketahui melalui skalogram. 
DOI: 10.31004 /obsesi.v5i2.907

Pada aspek ketidaksesuaian respons dengan model ideal seperti diperlihatkan oleh table 6 person fit order, terlihat bahwa yang paling tidak fit adalah guru/ resonden dengan kode , 11 dan 03 . Hal ini menunjukkan adanya kecenderungan pola tidak konsisten pada tiga responden dalam hal menjawab pertanyaan-pertanyaan dalam penelitian ini.

Untuk mengetahui kualitas keseluran instrumen, tabel ringkasan statistik berikut ini menunjukkan indikasi yang bagus baik untuk pola respon, kualitas aitem maupun interaksi antara aitem dan person.

\section{Tabel 6. table 17 Person Measure}

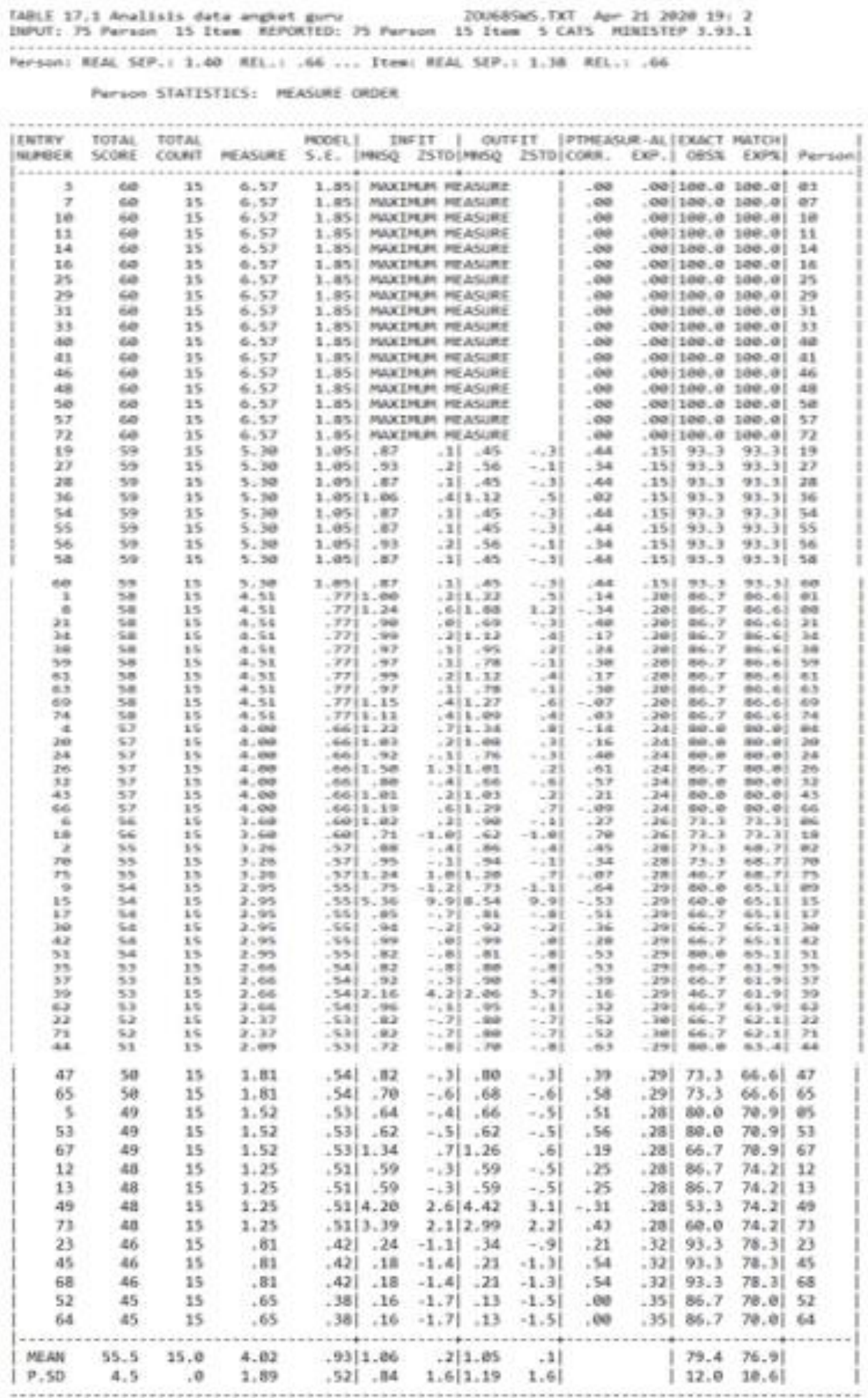


Tabel 6. table 17 Person Measure

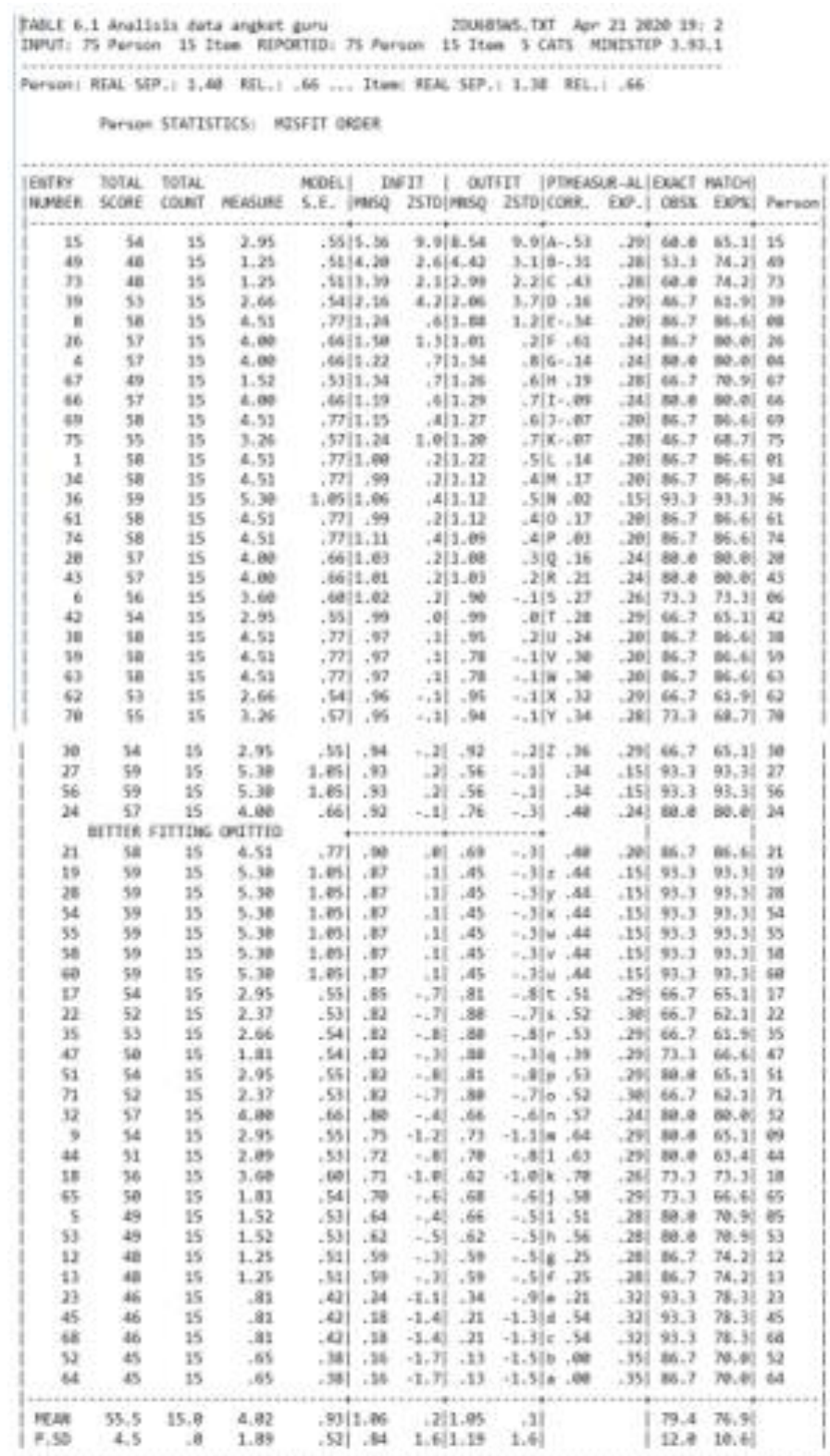

Tabel 7. table 17 Person Measure

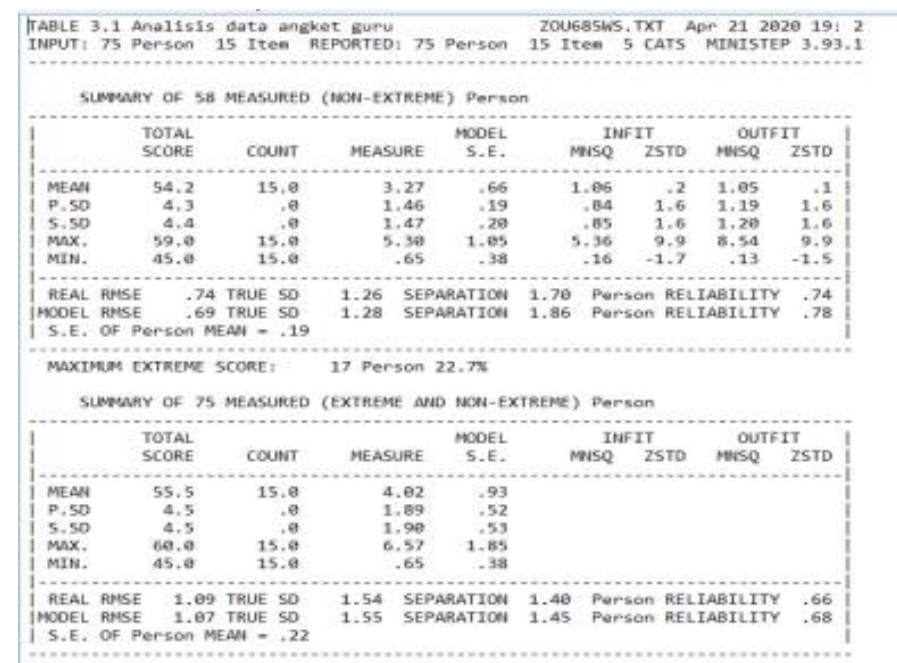


DOI: 10.31004/obsesi.v5i2.907

Pada ringkasan pola respons person, nilai infit dan outfit meansquare nilainya mendekati nilai sempurna $(1,0)$. Nilai infit dan outfit $z$-std mendekati nilai ideal yaitu 0,0 . Nilai reabilitas person juga menunjukkan reabilitas yang memuaskan $(0,74)$. Nilai separasi (separation) 1,70 . Nilai person strata yang memiliki harga 3 mengidikasikan adanya tiga kelompok responden (abilitas sangat setuju, setuju dan tidak setuju). Hal ini mencerminkan beragamnya abilitas (heterogen), yang menunjukan keterwakilan abilitas guru berdasarkan data dari angket yang telah diambil.

\section{Tabel 8 Summary Statistic}

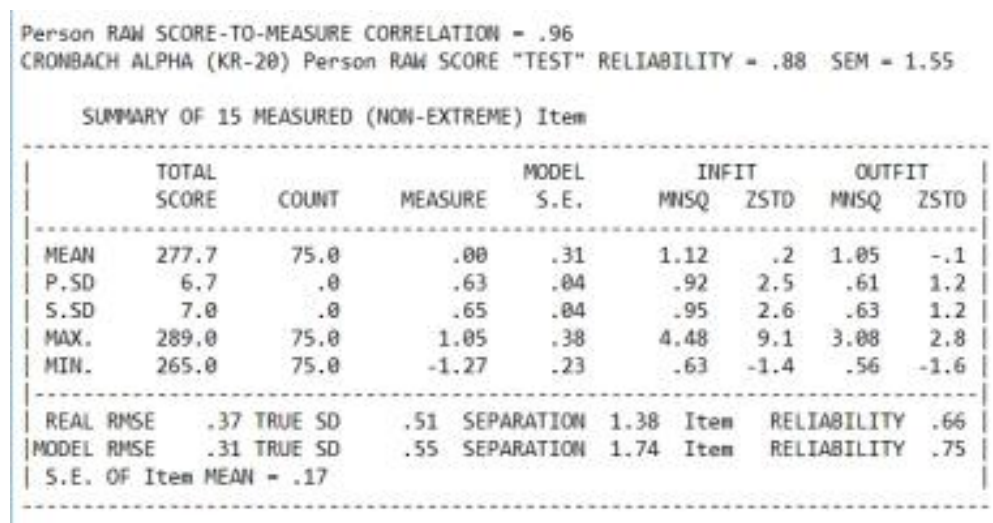

Pada aspek interaksi antara person dan aitem, maka indeks alpha cronbach adalah bagus $(0,88)$. Seperti halnya pada tabel sebelumnya, informasi mengenai instrumen juga menunjukan bahwa nilai infit dan outfit meansquare nilainya mendekati nilai seharusnya $(1,0)$, hal yang sama juga pada nilai infit dan outfit $z$-std (mendekati nilai 0,0). Indeks reabilitas aitem menunjukan sangat baik 0,66, dan nilai item separation yang 1,38 menunjukan bahwa butirbutir pertanyaan yang digunakan bisa mengelompokan abilitas guru.

Pada grafik fungsi informasi berikut terlihat bahwa informasi yang besar bisa didapat pada nilai measure antara $-1,6$ dan 1,5 , hal ini mengidenfikasikan pertanyaan yang digunakan tarafnya memang sedikit lebih sulit dan dapat memberikan info yang baik untuk individu yang abilitasnya sedikit lebih tinggi (sangat setuju) daripada abilitas sedang (setuju).

\section{Test Information Function}

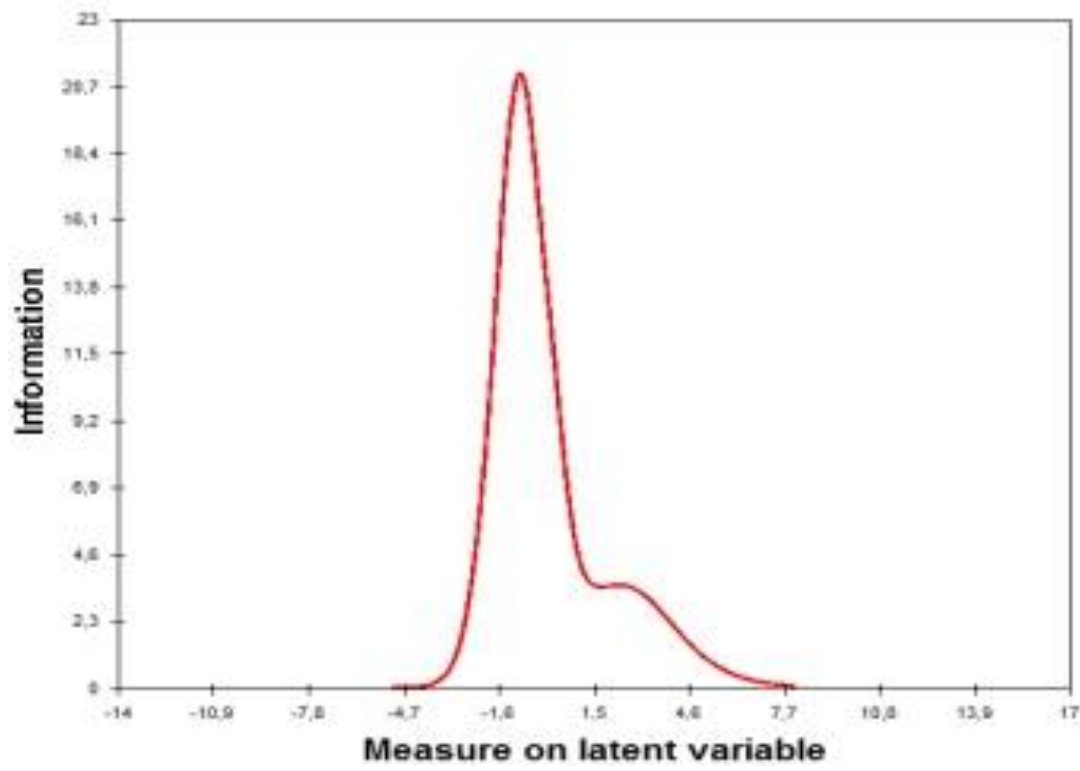

Grafik 1 fungsi informasi 
Hasil analisis di atas juga sejalan dengan penelitian yang dilakukan oleh (Risdianto, 2019a) yaitu tentang analisis kebutuhan pengembangan model blended learning berbasis web dan Augmented Reality. Berdasarkan data di atas kualitas angket yang telah di uji dengan metode rasch di atas maka hasil respon yang yang diperoleh dari data angket kebutuhan tentang kebutuhan pengembangan model blended learning berbasis MOOCs dapat dijadikan acuan perlunya pengembangan lebih lanjut.

Hasil penelitian ini juga didukung oleh bebagai penelitian terdahulu antara lain (Conole, 2016: 6) yang menyatakan bahwa MOOCs merupakan kursus online yang ditujukkan untuk partisipasi interaktif skala besar dan akses terbuka melalui web. Sehingga dengan MOOCs dapat memungkin menjadi alternatif media atau sumber belajar dalam pembelajaran daring. Senada dengan penyataan tersebut yang menyatakan MOOCs adalah model pembelajaran berbasis online yang dapat diakses oleh setiap orang diseluruh penjuru dunia secara gratis (Kop \& Carroll, 2011). MOOCs merupakan perkembangan terbaru dalam hal pendidikan jarak jauh (e-learning). MOOCs memberikan dampak yang nyata di Institusi Pendidikan Tinggi pada skala global, banyak sekali sekolah atau kampus yang menyediakan sistem pembelajaran MOOCs dalam program belajar mereka (Urrutia, Fielding, \& White, 2016). MOOCs hadir sebagai sebuah model baru pendidikan dan pembelajaran, yang menggunakan internet dalam menyampaikan materi perkuliahan di perguruan tinggi dan lembaga pendidikan bergengsi dunia, menciptakan semacam revolusi dan orang-orang ini saling bergabung untuk melakukan kursus berkelanjutan (Husna, 2019: 248) Terdapat dua buah model MOOCs yaitu xMOOCs dan cMOOCs (Margaryan, Bianco, \& Littlejohn, 2015: 77). Konsep xMOOCs (terutama didasarkan pada interaksi dengan konten dan pada dasarnya mengadopsi pendekatan pembelajaran behavioris), dan cMOOCs (yang fokus pada pemanfaatan kekuatan media sosial dan interaksi dengan teman sebaya, mengadopsi pendekatan pembelajaran connectivist) (Conole, 2016:1). Dari penjelasan tersebut maka pengembangan MOOCs dapat digunakan sebagai alternatif media pembelajaran khususnya dalam pembelajaran daring terutama bagi guru-guru PAUD. Hal ini senada dengan (Widayati, 2009) yang menyatakan bahwa Penggunaan media yang tepat dapat membantu guru meningkatkan mutu proses belajar membelajarkan dan hasil belajar peserta didik. Dalam program pemerintah, MOOCs akan menjadi prioritas dalam pengembangan pembelajaran di masa mendatang hal ini sesuai dengan program dirjen Belmawa akan menjadikan MOOCs sebagai target program pada tahun 2020 dan tahun berikutnya seperti pada gambar di bawah ini

OPTIMALISASI DAN SINERE

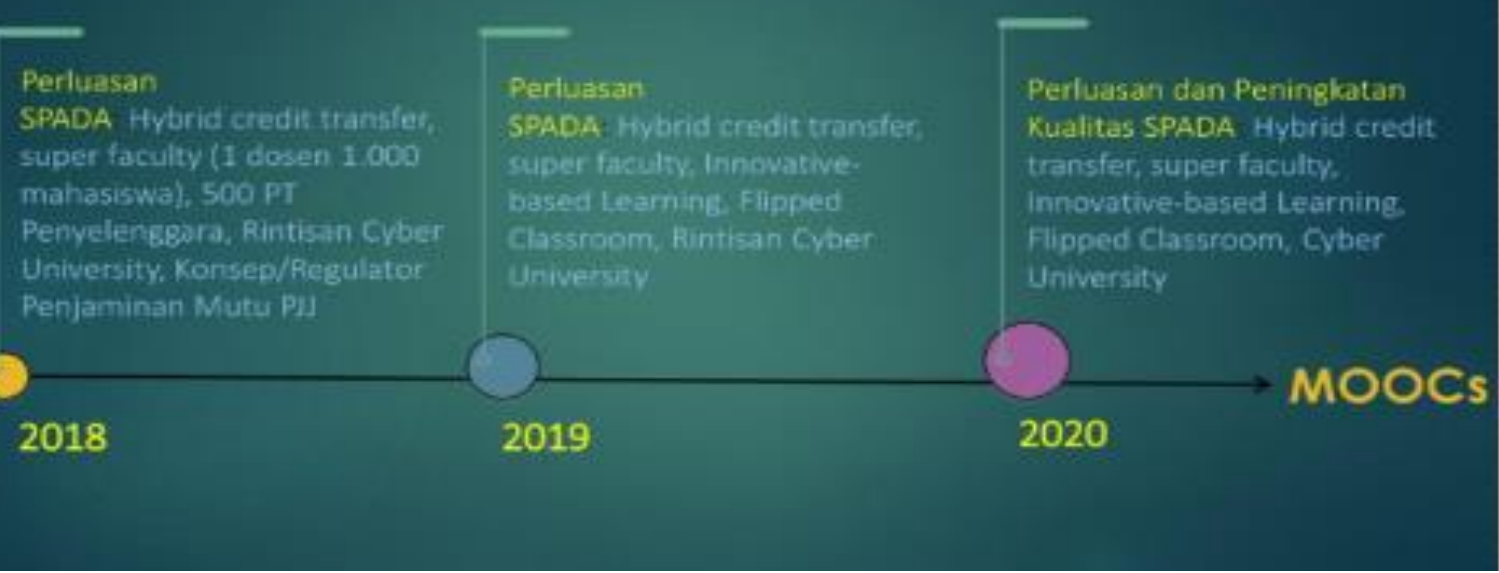

Gambar 4. Peluang Implementasi PJJ (belmawa, 2018) 


\section{SIMPULAN}

Berdasarkan analisis yang dilakukan terhadap hasil respon kebutuhan guru terhadap model blended learning berbasis MOOCs berbantuan augmented reality maka dapat disimpulkan bahwa kualitas dari angket respon terhadap kebutuhan model blended learning berbasis MOOCs berbantuan augmented reality ini adalah sangat baik. Sehingga dapat digunakan untuk menguji seluruh data yang digunakan. Kesimpulan dan penelitian ini adalah guru PAUD sangat setuju bahwa dibutuhkannya model blended learning berbasis MOOCs berbantuan augmented reality. MOOCs juga merupakan program skala prioritas pemerintah dalam perluasan dan peningkatan PJJ di masa datang sehingga implementasi untuk diterapkan untuk para pendidik PAUD sangat dibutuhkan saat ini khususnya di masa pandemi covid 19.

\section{UCAPAN TERIMA KASIH}

Penulis mengucapkan terimakasih kepada seluruh responden atau tenaga pendidik yang sudah bersedia bekerja sama untuk memperoleh data yang dibutuhkan dalam penelitian ini dan juga pihak-pihak lain yang sudah membantu

\section{DAFTAR PUSTAKA}

Conole, G. (2016). MOOCs as disruptive technologies: strategies for enhancing the learner experience and quality of MOOCs. Revista de Educación a Distancia (RED). https://doi.org/10.6018/red/50/2

Emigawaty. (2017). Perancangan Arsitektur Dan Purwarupa Model Pembelajaran Massive Open Online Course (MOOCs) di Perguruan Tinggi Menggunakan Layanan Mobile. Jurnal Ilmiah DASI, 18, 25-30. Retrieved from https:/ / media.neliti.com/media/publications/90109-ID-perancangan-arsitekturdan-purwarupa-mod.pdf

Fandianta, Sanjaya, G. Y., \& Widyandana. (2013). Meningkatkan Pengetahuan Mahasiswa dengan Memberikan Fleksibilitas Belajar Mengajar melalui Metode Blended Learning. Jurnal Pendidikan Kedokteran Indonesia, 2(2), 1-8.

Ismail, M. E., Hashim, S., Ismail, I. M., Ismail, A., Daud, K. A. M., \& Khairudin, M. (2018). Penggunaan Massive Open Online Course (Mooc) Dalam Kalangan Pelajar Vokasional. Journal of Nusantara Studies, 3(1), 30-41.

Khoiroh, N., Munoto, \& Anifah, L. (2017). Pengaruh Model Pembelajaran Blended Learning Dan Motivasi Belajar Terhadap Hasil Belajar Siswa. Jurnal Penelitian Ilmu Pendidikan, 10(2), 97-110.

Kop, R., \& Carroll, F. (2011). European Journal of Open, Distance and E- Learning. 1-6. Retrieved from https:/ / www.eurodl.org/ ?p=special\&sp=articles\&inum=2\&article=457

Liani, E., Hamdani, D., \& Risdianto, E. (2018). Penerapan Model Problem Based Learning dengan Metode Brainstorming untuk Meningkatkan Kemampuan Pemecahan Masalah Siswa di SMAN 3 Kota Bengkulu. Jurnal Kumparan Fisika, 1, 20-24.

Maiza, Z., \& Nurhafizah, N. (2019). Pengembangan Keprofesian Berkelanjutan dalam Meningkatkan Profesionalisme Guru Pendidikan Anak Usia Dini. Jurnal Obsesi : Jurnal Pendidikan Anak Usia Dini, 3(2), 356. https:/ / doi.org/10.31004/obsesi.v3i2.196

Margaryan, A., Bianco, M., \& Littlejohn, A. (2015). Instructional quality of Massive Open Online Courses (MOOCs). Computers and Education, 77-83. https://doi.org/10.1016/j.compedu.2014.08.005

Mustaqim, I., \& Kurniawan, N. (2017). Pengembangan Media Pembelajaran Berbasis Augmented Reality. Jurnal Edukasi Elektro, 1(1), 36-48. https://doi.org/10.24252/lp.2018v21n1i6

Oktarina, S., Budiningsih, A., \& Risdianto, E. (2018). Model Blended Learning Berbasis Moodle (1st ed.). Jakarta: Halaman Moeka. 
Pebriana, P. H. (2017). Analisis Penggunaan Gadget terhadap Kemampuan Interaksi Sosial pada Anak Usia Dini. Jurnal Obsesi: Jurnal Pendidikan Anak Usia Dini, 1(1), 1. https://doi.org/10.31004/obsesi.v1i1.26

Peranti, Purwanto, A., \& Risdianto, E. (2019). Pengembangan Media Pembelajaran Permainan Mofin ( Monopoli Fisika Sains ) Pada Siswa Sma Kelas X. Jurnal Kumparan Fisika, 2(1), 41-47.

Prayitno, E., \& Masduki, L. R. (2017). Pengembangan Media Blended Learning Dengan Model Flipped Classroom Pada Mata Kuliah Pendidikan Matematika Ii. JIPMat, 1(2), 121-126. https:// doi.org/10.26877/jipmat.v1i2.1238

Putrawangsa, S., \& Hasanah, U. (2018). Integrasi Teknologi Digital Dalam Pembelajaran Di Era Industri 4.0 Kajian dari Perspektif Pembelajaran Matematika. Jurnal Tatsqif, 16(1), 42-54. https://doi.org/10.20414/jtq.v16i1.203

Putri, R. M., Risdianto, E., \& Rohadi, N. (2019). Pengembangan Media Pembelajaran Interaktif dengan Menggunakan Adobe Captivate pada Materi Gerak harmonik Sederhana. 2(2), 113120.

Risdianto, E. (2019a). Development of Blended Learning Based on Web and Augmented Reality. 1st International Conference on Educational Sciences and Teacher Profession (ICETeP 2018, 295.

Risdianto, E. (2019b). Kepemimpinan Dalam Dunia Pendidikan Di Indonesia di Era Revolusi Industri 4.0. 1-12.

Setiawan, A. B., \& Nugraha, A. C. (2017). Pengembangan Media Pembelajaran Berbasis Augmented Reality Pengenalan Komponen Sistem Kendali Elektromagnetik. Prodi Pendidikan Teknik Elektro, 7(5), 409-415.

Sriwahyuni, I., Risdianto, E., \& Johan, H. (2019). Pengembangan Bahan Ajar Elektronik Menggunakan Flip Pdf Professional Pada Materi Alat-Alat Optik Di Sma. Jurnal Kumparan Fisika, 2(3), 145-152. https:/ / doi.org/10.33369/jkf.2.3.145-152

Sugiyono. (2010). Metode Penelitian Pendidikan (Pendekatan Kuantitatif, Kualitatif, dan RED). Bandung: ALFABETA.

Sumintono, B \& Widhiarso, W. (2015). Aplikasi Pemodelan Rasch pada Asesmen Pendidikan. (October), 1-127.

Suryani, Y. E. (2018). Aplikasi Rasch Model dalam Mengevaluasi Intelligenz Structure Test (IST). Psikohumaniora: Jurnal Penelitian Psikologi, 3(1), 73-99. https://doi.org/10.21580/pjpp.v3i1.2052

Urrutia, M. L., Fielding, S., \& White, S. (2016). Professional Development Through MOOCs in Higher Education Institutions: Challenges and Opportunities for PhD Students Working as Mentors. Journal of Interactive Media in Education, 2016(1), 1-10. https://doi.org/10.5334/jime.427

Wardani, D. N., Toenlioe, A. J. E., \& Wedi, A. (2018). Daya Tarik Pembelajaran Di Era 21 Dengan Blended Learning. Jurnal Kajian Teknologi Pendidikan (JKTP), 1(1), 13-18.

Widayati, T. (2009). Pengembangan Media Pembelajaran Tutor Paud Dalam Menggali Perilaku Kerjasama Anak Usia Dini Melalui Gerak Dan Lagu. Jiv, 4(2), 113-124. https://doi.org/10.21009/jiv.0402.1

Zamzami, E. M. (2020). Aplikasi Edutainment Pendukung Pembelajaran Jarak Jauh TK Merujuk Standar Nasional PAUD. Jurnal Obsesi : Jurnal Pendidikan Anak Usia Dini, 5(2), 985-995. https://doi.org/10.31004/obsesi.v5i2.750 